\title{
On Marx 's World History Theory and Contemporary Chinese Socialism
}

\author{
Lu Bai \\ Harbin University of Commerce, Harbin Heilongjiang, 150028, China
}

Key words: Marx, World history theory, Contemporary, Socialism with Chinese characteristics.

\begin{abstract}
Marx's theory of world history mainly focuses on the impact of the general development of productive forces and exchanges on the social development process. It is clear that the mutual reference and follow-up of civilization can greatly promote the rapid development of history. The development of history in the development of jump is a relatively common phenomenon. This will be able to make a correct interpretation of China's contemporary socialist construction situation, that is clearly explain China's economic and cultural development in the general level of how to cross the capitalist society in the process of building the inevitable face of the "Caudine Forks "And entered the socialist construction state and built the contemporary Chinese characteristics of socialism, and in-depth study of this issue provides a corresponding theoretical support.
\end{abstract}

\section{Introduction}

Marx's theory of world history in the study of "capitalist mode of production to promote history to the world history change" as the foundation, in the study of theoretical interpretation of emphasis on the general development of productive forces and exchanges on the social development process have an important impact on the accelerated society Development process play a certain role in promoting. Therefore, in view of the actual situation of China's contemporary socialist construction, in the process of discussing how China crossed the "Caudine Gorge" and entered into the relevant issues of the socialist construction period, it should try to deepen the question from the perspective of Marx's world historical theory And then on the relevant issues to form a relatively clear, systematic understanding of the development of socialism with Chinese characteristics and development to provide the appropriate theoretical support.

\section{Marxist World History Theory and the Choice of Contemporary Chinese Characteristic Socialism}

From the perspective of a certain degree of political philosophy research and analysis, the process of contemporary Chinese construction will eventually choose the characteristics of the socialist road in essence is the result of world history in-depth development. On the one hand, the backward level of low-productivity countries across the "Caudine Forks" to achieve leap-style development may be derived from the civilizations between the emulation and reference, and between the civilizations to follow and learn from the role of world history jump Development has become a routine phenomenon, to promote some countries in the leap-style development support and catch up with advanced countries. On the other hand, contemporary China in the construction process of the characteristics of the socialist road exploration and bipolar world division of labor there is a relatively close relationship [1]. The bipolar world division of labor itself is the inevitable result of world history and is the direct result of the development and function of the capitalist world market system. However, although the capitalist world is increasingly promoting the world as a whole in the development process, it is different in the whole Of the country and the nation also showed unbalanced 
development, and in the process of capitalist development of the backward countries of the exploitation and plunder, and ultimately lead to the emergence of polarization in the history of the world, and the polarization of the world history must choose for backward development The development of the country to explore the leap forward provides some necessary conditions. In the process of development, the Chinese Communist Party led the Chinese people to learn from the successful experiences of the western developed countries and explored the characteristic socialism which was suitable for China's national conditions. In the process of developing China, the Chinese Communist Party was guided by the successful experience of the western developed countries. Road, to achieve the capitalist "Caudine Forks" across, has made a historic leap in development, the development trend of socialism with Chinese characteristics along with the formation. It can be seen that Marx's theory of world history can make a reasonable explanation of the choice of socialism with Chinese characteristics. It is not the subjective thought of the Communist Party of China, but the mutual reference of civilization in the world history and the formation of bipartite division of labor to promote China's development process To achieve the capitalist "Caudine Forks" across, and ultimately explore with China's basic national conditions to adapt to the characteristics of the socialist road.

\section{Marx 's World History Theory and Contemporary Socialism with Chinese Characteristics}

There is a close connection between the cause of socialism construction with Chinese characteristics and the development of world history. It must complete the research and construction work under the conditions of world history, so it is closely related to the development of world history. Thus, in the process of studying the cause of socialism with Chinese characteristics, Marx's theory of world history should be introduced to open up a new perspective and form a deeper understanding of the construction of socialism with Chinese characteristics. On the basis of Marx's theory of world history, this paper analyzes the cause of socialism with Chinese characteristics and puts forward some suggestions.

\section{Contemporary Socialism with Chinese Characteristics Must Develop Social Productive Force in the Course of Construction and Development}

The development of social productive forces is a necessary condition for boosting economic construction. If there is no general development of productive forces in social construction, it will lead to the emergence of extreme poverty and the phenomenon of universal poverty. Social unrest will also arise. The study and analysis of Marx's theory of world history can reveal that in the view of Marx's research, the liberation of each individual individual should grasp the law of "transforming history into world history", explore the consistency of change, and then transform the history into the world History "with the support of the pursuit of a greater degree of freedom and liberation. In other words, if the history of the world can not be comprehensive and in-depth development, the complete liberation of mankind is out of the question. From this research level, China's pursuit of communist society is laid on the basis of a high degree of development of social productive forces, must be a high degree of development of social productive forces as a prerequisite [2]. Although the analysis of the history of the world, communism is the cause of the world's historic construction, related to the development of all mankind, and our country in the process of exploring the development of communism, but not as Marx envisioned with the world to explore simultaneously, But first in the East society in the low level of productivity in the country broke out of the revolution, and then across the capitalist system is bound to face the "Kafu Ding Gorge", directly into the socialist society construction period, but need to pay attention to is that contemporary China The development of the characteristics of socialism can not be separated from the world conditions for analysis and interpretation of the real socialist countries in the construction of the cause of socialism in the process of the need to strengthen the economic base of attention, only to ensure a strong solid economic base, to break through capitalism The world's obstacles, and ultimately under the pressure of world history to obtain the ideal survival and development space. This means that the cause of socialist construction 
has obvious superiority, and the core reason is that the productivity of socialist society can be faster and higher than the capitalist society, and can gradually increase the level of productivity On the basis of the realization of the people's material and cultural life improvement [3]. The problem of contemporary socialist construction with Chinese characteristics is mainly that the level of contemporary Chinese productive forces is still relatively backward, even after more than half a century of continuous adherence and efforts to explore the level of productivity has been greatly developed, and even in some areas already To achieve the transcendence of the world's leading level, but still did not fundamentally reverse the problem of lack of productive forces, the cause of contemporary Chinese characteristics of socialism had a certain adverse impact. It can be seen that, based on the guidance of Marx's theory of world history, contemporary China must still adhere to economic construction as the core in the process of building a characteristic socialist society, vigorously develop social productive forces, and thus consolidate the economic base and provide good for the construction of characteristic socialism support.

\section{Contemporary cause of socialism with Chinese characteristics must adhere to the deep development of opening up}

From the theory of Marx's world history, we can see that the universal development of communication is a prerequisite for the development of world history. Only by realizing the general development of communication, the individual in society can gradually break through the limitations of the nation and region and realize the production of the whole world And spiritual production links, in the personal development of the global realization of this special comprehensive production capacity. At the same time, the deep development of world history at the world level to a certain extent, to promote universal exchanges become a necessary and inevitable, that is, it is in the development of the general support of exchanges, the world really become an interdependent unity of the whole [ 4]. In essence, the general development of communication not only can promote the deepening of world history, but also put forward some requirements to the development of world history, that is to say that the contemporary world must be an open world. The study and analysis of the contemporary open world, found that there are two opposing social system - the capitalist system and the socialist system. Among them, the capitalist social system in the current world history occupies a considerable range of human civilization development results, grasp the advanced conditions of productive forces, and for the real socialism system, in essence, compared to the capitalist system can reflect a certain But its construction is based on the relatively backward level of productivity and oriental civilization, so both in the development process of their own characteristics, in order to seek a win-win situation, it should realize the capitalist society and the socialist society Are open to each other. Contemporary China as a developing country, in the process of building a characteristic socialist system through in-depth exploration of opening up, you can actively absorb and learn from capitalism created by the advanced productive forces, and capitalist society in the construction process should also try from the socialist The country to explore the development of a way out to achieve the target market positioning. In the context of the development of contemporary world integration, only to adhere to open to the outside world and explore the in-depth development of opening up to be able to find their own position in the world building, access to the recognition and recognition of the world. In the cause of socialist construction with Chinese characteristics, China is still in the process of development to adhere to the basic national policy of opening to the outside world, and to promote the development of opening up to the outside world, building the socialist society with Chinese characteristics for the world. Only in this way can the contemporary socialism system with Chinese characteristics be able to win the more prominent advantages than the capitalist society in the process of construction and development, and actively absorb and learn from all the civilized achievements created by mankind in the development process. The construction of developed countries to explore the socialist modernization drive, the introduction of more advanced mode of operation and management methods to promote the cause of socialist construction in the new era of good development. 


\section{The Construction of Socialism with Chinese Characteristics Must Adhere to the Fundamental System}

In the theory of Marxist world history, world history is a relatively unified whole, in which the existence of various nationalities, countries and regions are their important constituent elements, so the world history system in different countries, different nationalities and different regions in the world The process of historical development in the interpretation of a different role, but also play a variety of functions. In the process of exploring the integration of world history, we should realize that we can go into the world history and adhere to the national characteristics can coexist, that is, contemporary China in the world historical background to explore the characteristics of socialism development path, in the world to seek new development At the same time should also adhere to the socialist fundamental system, to maintain national characteristics. In this process, the socialist cause builder must clearly recognize that "overall Westernization" does not make a nation new, but in essence it represents the nation's vitality has gradually become depleted. Therefore, in the process of exploring the direction of development from the open, we should also pay attention to maintaining the most essential national characteristics in the open, adhere to the national spirit [5]. China as an important developing country in the history of the world, blindly adhere to open to the outside world, absorb the experience of other countries can not be fully developed, only in the independent, self-reliance on the basis of the completion of reference work, combined with the basic characteristics of socialism with Chinese characteristics National conditions of the system, ideas, technology, etc. to adjust, to be able to achieve self-development, independent of the world's national forest. In other words, in the process of developing contemporary Chinese characteristics of socialism, the reference of Western capitalism must be based on a certain degree of internalization and innovation can really play a reference role, if the reference to the loss of the original support, will be completely copied, Is a kind of "crawling" is not desirable. Therefore, in the process of building and developing the characteristics of socialism in the new period, China still needs to adhere to deepen the exploration and opening up, absorb the advanced technology and experience of Western capitalist countries, and should be based on the original Principle, and ultimately to achieve "for my use" the ultimate goal. Only by simply starting from the basic national conditions of China, adhere to the fundamental system of socialist construction, adhere to the construction of socialism with Chinese characteristics and the construction of the principle, in order to open and learn at the same time adhere to the national characteristics, to explore suitable for China's actual situation of the development path, And provide good support for the realization of China's socialist modernization drive.

\section{Conclusions}

To sum up, from the perspective of Marx's world history theory of contemporary Chinese characteristics of the socialist construction of the cause of interpretation, to the contemporary Chinese characteristics of the cause of socialism to form a clear and objective understanding, and then for the development of socialism with Chinese characteristics development direction Corresponding guidelines to promote the realization of China 's socialist modernization goal. Therefore, in the process of studying the cause of building socialism with Chinese characteristics in the new period, we should pay attention to the study and analysis of Marx's world history theory, and provide the corresponding theoretical reference for the construction of socialism with Chinese characteristics.

\section{Acknowledgement}

A project of Philosophy and Social Sciences in Heilongjiang Province in 2015: A Practical Study of China's Roads Based on Marx's World History Theory (No. 15KSD03).

\section{References}

[1] Qi Lingling. On Marx 's theory of world history, Technology horizon, 2015(31):193-193,216. 
[2] Zhang Tianyong, Qi Tiantian. (6): 63-67 (in Chinese), .Jiangsu Social Sciences, 2014 (6): 63-67.

[3] Liu Yajun. The Inspiration of Marx's World History Theory to Modern Moral Education Goals, Hubei Social Sciences, 2015 (3): 170-176.

[4] Yang Yongbing. Marx's Theory of World History in China, Journal of Theoretical, 2016 (8): 62-66.

[5] Gao Lihua, Kong Yang. On the Choice of Socialism with Chinese Characteristics from the Perspective of Marx 's Two World History, Journal of Northeast Normal University (Philosophy and Social Sciences), 2015(2):17-21. 